\title{
PELAKSANAAN ASAS ITIKAD BAIK DALAM PERJANJIAN KREDIT SECARA LISAN DENGAN JAMINAN GADAI MOBIL
}

\author{
I Gede Surya Mardita putra, I Nyoman Putu Budiartha, Desak Gde Dwi Arini \\ budiarthaputu59@gmail.com, arinidesak1966@gmail.com \\ Fakultas Hukum, Universitas Warmadewa, Denpasar-Bali, Indonesia
}

\begin{abstract}
Abstrak
Pada umumnya ketika seseorang melakukan kegiatan pinjaman kepada pihak bank maupun persero, maka akan dibuat suatu perjanjian yang telah disepakati oleh kedua belah pihak. Dalam hal ini seringkali terjadi perjanjian namun tanpa adanya kesepakatan yang ditulis dengan kata lain hanya melalui lisan. Tujuan penelitian ini untuk menganalisa sahnya perjanjian kredit secara lisan dengan jaminan gadai mobil dan pelaksanaan asas itikad baik dalam perjanjian kredit secara lisan dengan jaminan gadai mobil. Tipe penelitian yang digunakan adalah penelitian hukum secara empiris dengan menggunakan sumber data primer dan data sekunder yang diperoleh dari penelitian di lapangan, literatur dan peraturan perundang-undangan yang berkaitan dengan permasalahan yang diangkat. Teknik pengumpulan data dilakukan dengan pencatatan dan dokumentasi. Dalam rangka mendapatkan pemaparan yang jelas, data tersebut kemudian dianalisis dan disajikan secara kualitatif. Hasil penelitian mengungkapkan bahwa perjanjian kredit yang dilakukan secara lisan yang dilakukan oleh Pihak 1 dan Pihak 2 telah memenuhi semua ketentuan syarat sahnya perjanjian pasal 1320 KUHPerdata. Terdapat kesepakatan meminjam uang dengan memberikan jaminan sebuah mobil Toyota. Pihak 1 telah melaksanakan dengan itikad baik hal-hal yang disepakati dalam perjanjian yang yang dibuat bersama dengan pihak 2 tanpa terdapat pelanggaran apapun dengan melakukan pelunasan terhadap pinjaman yang dilakukannya kepada Ketut sebesar 30\% dari yang diperjanjikan dalam tempo waktu 5 bulan dengan bunga atas pinjaman tersebut sebesar $10 \%$ per bulan.
\end{abstract}

Kata Kunci: Gadai, Itikad Baik, Perjanjian

\begin{abstract}
In general, when someone carries out a loan to a bank or company, an agreement will be made that has been agreed by both parties. In this case, there is an agreement but it does not written in the paper. The purpose of this research is to analyze the validity of the oral credit agreement with the car pawn guarantee and the implementation of the good faith principle in the oral credit agreement with the car pawn guarantee. The type of the research used is empirical by using primary data sources and secondary data obtained from field research, literature and legislation relating to the issues. The data collection techniques are carried out by recording and documentation. In order to get a clear explanation, the data is analyzed and presented qualitatively. The result of the research reveals that the credit agreement made orally by Party 1 and Party 2 had fulfilled all the provisions of the validity of the agreement under Article 1320 of the Civil Code. There is an agreement to carry money off by guaranteeing a Toyota car. Party 1 has carried out in good faith the matters agreed in the agreement made together with party 2 without any violation by making repayments of the loan he made to Ketut in the amount of $30 \%$ of what was agreed within 5 months with interest on the loan at $10 \%$ per month.
\end{abstract}

Keywords: Pawn, Good Faith, Agreement

\section{PENDAhuluan}

Perkembangan zaman dan teknologi terhadap pelaku ekonomi kredit atau pembiayaan mendorong sebagian pelaku ekonomi pemerintahan maupun masyarakat baik perorangan maupun badan hukum yang memerlukan dana besar. Pihak yang memerlukan dana pada umumnya akan melakukan pinjaman kepada bank ataupun badan hukum perorangan, dimana akan membuat suatu perjanjian. Pemberian kredit tidak dapat dilakukan oleh bank akan tetapi dapat juga dilakukan oleh siapa saja yang mempunyai kemauan dan kemampuan untuk itu melalui utang piutang dengan pembayaran secara cicilan antara kreditur yang memberi jaminan dan debitur penerima pinjaman di pihak yang lain (Tiong, 1985). 
Jaminan hutang yang objeknya masih tergolong dalam benda bergerak akan tetapi kekuasaan atas benda tersebut tidak beralih dari debitur kepada kreditur (Fuady, 2003). Perjanjian gadai mobil sering dilakukan karena sangat membantu para pihak yang membutuhkan dana cepat. Dalam pasal 1313 KUHPerdata menentukan bahwa perjanjian sebagai suatu perbuatan dengan mana satu orang atau lebih mengikatkan ctirinya terhadap satu orang lain atau lebih dengan memenuhi syarat-syarat sebagaimana yang diatur dalam pasal 1320 KUHPerdata, yaitu sepakat, kecakapan, suatu hal tertentu dan suatu sebab yang halal.

Para pihak dalam membuat sebuah perjanjian bebas untuk menentukan isi perjanjian yang akan dibuat, selama hal tersebut tidak melanggar norma, undang-undang, dan ketentuan yang berlaku. KUHPerdata khususnya pada Pasal 1150-1160 telah mengatur gadai yang menjadi jaminan benda bergerak oleh kreditur yang diperoleh dari debitur yang menjadi jaminan utang sebagai jaminan pelunasan utangnya nanti. Gadai sebagai salah satu hak yang diperoleh bagi kreditur atau suatu jaminan barang bergerak yang diserahkan kepadanya atau oleh kuasanya sebagai jaminan atas utangnya, dan memberi wewenang kepada kreditur untuk mengambil pelunasan atas piutangnya dengan mendahului kreditur-kreditur lainnya, tanpa pengecualian biaya penjualan sebagai pelaksanaan atas runtutan kepemilikan atau kepenguasaan dan biaya penyelamat barang tersebut yang harus didahulukan.

Pada tulisan ini, terdapat contoh kasus perjanjian gadai mobil berdasarkan itikad baik yang dilakukan lokasi perjanjian Perumahan Wahyu Bemasi Permai, Banjar Bemasi Buduk, Desa Buduk, Kecarnatan Mengwi, Kabupaten Badung 23 Maret 2017. Fery sebagai pihak debitur rnerninjam uang sebesar Rp30.000.000,- (tiga puluh juta Rupiah) kepada I Ketut Putrayasa sebagai pihak kreditur, Fery meminjam uang kepada Ketut dengan memberikan jaminan sebuah mobil Toyota Vios kepada Ketut. Dengan rnelakukan perjanjian lisan yaitu atas itikad baik, dimana perjanjian ini telah disepakati atas kepercayaan tanpa ada tipu daya muslihat. Di dalam perjanjian, Fery akan melunasi utang kepada Ketut sebesar 30 juta dengan tempo 5 (lima) bulan dan sudah menyepakati bunga sebesar 10\% (sepuluh persen) perbulan, perjanjian ini dilakukan karena hubungan teman dekat. Selama 5 (lima) bulan pertama memang Fery membayar penuh utang kepada Ketut, dan Fery ingin meminjam uang lagi kepada Ketut dengan alasan ingin mudik dan anaknya yang sedang sakit, Ketut rnerasa iba karena apa yang disampaikan oleh Fery maka Ketut memberikan uang lebih yaitu sebesar Rp. 40.000.000,(empat puluh juta Rupiah), setelah 5 (lima) bulan berlalu dan jatuh tempo sudah lewat Fery kunjung tidak ada kabar. Ketut penasaran kenapa Fery tidak kunjung ada kabar maka dia menanyakan kerabat Fery yang mengatakan bahwa Fery sudah tidak diam di kampung halamannya lagi dan rnobil yang rnenjadi jaminan piutangnya tersebut tidak terdaftar, karena Buku Pemilik Kendaraan Berrnotor (BPKB) ditahan oleh pihak dealer Toyota dan Surat Tanda Kendaraan Bermotor (STNK)nya palsu.

Hingga saat ini Fery tidak ada kabar sama sekali dan tidak rnerniliki itikad tidak baik dalam melaksanakan perjanjian yang telah disepakatinya bersama dengan Ketut serta telah melakukan perbuatan wanprestasi. Setelah berpikir lama karena ketut merasa dirugikan, Ketut ingin menjual mobil Toyota Vios tersebut di muka umum dengan syarat-syarat yang lazim berlaku, dengan rnaksud untuk mengambil pelunasan jumlah piutangnya beserta bunga dan biaya dari pendapatan penjualan tersebut, tetapi rnasih susah untuk rnenjualnya dikarenakan rnobil tersebut tidak terdaftar atau bodong.

Perjanjian tidak tertulis adalah perjanjian sah dalam perspektif hukum perdata selama tidak bertentangan dengan Pasal 1320 Kitab Undang-Undang Hukum Perdata (Vijayantera, 2020). Maka dalam hal ini pembuktian perjanjian yang dibuat secara lisan yaitu kedua bela pihak berunding kembali dan membuat perjanjian baru dengan itikad baik. Ketika kesepakatan telah ada, maka perjanjian harus dibuat secara tertulis dengan melibatkan pihak ketiga (Wauran et al., 2020). Menurut (Sirait et al., 2020) hal ini merupakan asas itikad baik dalam pembuatan dan pelaksanaan substansi perjanjian akan tampak dari adanya kepercayaan dan kemauan baik serta tanggungjawab didalam pemenuhannya oleh para pihak. Dengan itikad baik, terdapat kewajiban untuk berperilaku secara tepat, serta kesopanan terkandung didalamnya (Amalia et al., 2018).

Maka berdasarkan uraian diatas, tujuan dari penelitian ini yaitu untuk menganalisa sahnya perjanjian kredit secara lisan dengan jaminan gadai mobil dan pelaksanaan asas itikad baik dalam perjanjian kredit secara lisan dengan jaminan gadai mobil 


\section{METODE PENELITIAN}

Tipe penelitian yang digunakan oleh penulis adalah penelitian hukum secara empiris dengan rnenggunakan surnber data primer yang didapatkan secara langsung dari keterangan inforrnan dan responden dan data sekunder yang diperoleh dari penelitian di lapangan, literature dan peraturan perundang-undangan yang berkaitan dengan perrnasalahan yang diangkat. Teknik pengumpulan data dilakukan dengan pencatatan dan dokumentasi dengan lokasi penelitian di Perumahan Wahyu Bemasi Permai, Jl. Rahayu 4 No. 9, Br. Bemasi Buduk, Kec. Mengwi, Kab. Badung, Prov. Bali. Dalam rangka mendapatkan pemaparan yang jelas, data tersebut kemudian dianalisis dan disajikan secara kualitatif.

\section{HASIL DAN PEMBAHASAN}

\section{Sahnya Perjanjian Kredit Secara Lisan dengan Jaminan Gadai Mobil}

Syarat sahnya perjanjian dengan jaminan gadai mobil telah diatur dalam ketentuan pasal $1320 \mathrm{KU}$ HPerdata, diantara lain sepakat mereka untuk mengikatkan dirinya dalam perjanjian yang telah disetujui, baik secara tertulis, lisan, simbol-simbol tertentu atau berdiam diri. Perjanjian secara lisan banyak dan sering terjadi dalam bermasyarakat dikarenakan lebih mudah dan praktis (Miru, 2007). Syarat selanjutnya adalah kecakapan yang berarti seorang oleh hukum dianggap belum atau tidak cakap melakukan sebuah kontrak jika belum berumur 21 tahun, masih berada dibawah pengampuan, dan pada umumnya semua orang kepada undang-undang telah melarang membuat suaru perjanjian tertentu.

Hal tertentu merupakan syarat selanjutnya yang berarti suatu kontrak yang objek perjanjiannya harus jelas dan ditentukan oleh kedua belah pihak, objek perjanjian yang ditentukan tersebut dapat berupa barang maupun jasa, tidak berbuat sesuatu, dan sebab yang halal berarti isi kontrak tersebut tidak bertentangan dengan Peraturan Perundang-Undangan. Sahnya perjanjian kredit secara lisan dengan jaminan gadai mobil yang dilakukan oleh Fery dan I Ketut Putrayasa yang berlokasi di Perumahan Wahyu Bemasi Permai, Jl. Rahayu 4 No. 9, Br. Bemasi Buduk, Kec. Mengwi, Kab. Badung, Prov. Bali bahwa para pihak telah sepakat untuk mengikatkan diri di dalam perjanjian yang telah diserujui dengan cara lisan yaitu Fery sebagai pihak debitur meminjam uang sebesar Rp30.000.000,-(tiga puluh juta Rupiah) kepada I Ketut Putrayasa sebagai pihak kreditur dengan memberikanjaminan sebuah mobil Toyota Vios. Para pihak rnerniliki kecakapan karena telah berumur diatas 21 tahun.

Perjanjian lisan yang dibuat oleh Fery dan I Ketut Putrayasa telah terdapat hal tertentu sebagaimana dipersyaratkan oleh Pasal 1320 KUHPerdata. Objek perjanjian telah jelas berupa barang yang ditentukan oleh para pihak. Selanjutnya, suatu sebab yang halal sebagaimana dipersyaratkan oleh Pasal 1320 KUHPerdata juga telah terpenuhi karena perjanjian lisan yang dibuat oleh Fery dan I Ketut Putrayasa tidak bertentangan dengan Peraturan Perundang- Undangan yang berlaku. Perjanjian kredit secara lisan dengan jaminan gadai mobil yang dilakukan oleh Fery dan 1 Ketut Putrayasa telah memenuhi semua syarat-syarat yang diatur dalam pasal 1320 KUH Perdata maka wajib untuk dipenuhi serta berlaku sebagai hukum. Perjanjian lisan merupakan perjanjian yang sah karena telah memenuhi unsur kata sepakat, sehingga kedua belah pihak yang melakukan perjanjian tersebut wajib untuk rnelakukan dan memenuhi prestasi dari apa yang telah disepakati sebagaimana yang diatur dalam pasal 1234 KUHPerdata.

\section{Pelaksanaan Asas Itikad Baik dalam Perjanjian Kredit Secara Lisan dengan Jaminan Gadai Mobil}

Pelaksanaan asas itikad baik dalam perjanjian ini kredit yaitu terkait dengan kejujuran pada sikap batin seseorang pada waktu dilaksanakan perbuatan hukum. Para pihak harus melaksanakan hal-hal yang telah disampaikan secara lisan berdasarkan kepercayaan atau keyakinan, kejujuran serta kemauan baik dari para pihak. Itikad baik dalam pelaksanaan kredit dilakukan sebagai suatu sikap batin atau kejiwaan manua yang jujur, terbuka atau tidak ada yang disembunyikan, tulus iklas, dan bersungguh-sungguh (Atmaja \& Budiartha, 2018).

Pelaksanaan asas itikad baik dalam perjanjian kredit secara lisan memberi hak kepada pemberi gadai untuk menuntut apabila barang gadai tersebut hilang atau mundur akibat dari kelalaian pemegang jaminan gadai dan berhak mendapat kembali barang yang digadaikan apabila hutangnya dibayar lunas (Untung, 2000). Kewajiban pemberi gadai ialah rnenyerahkan barang yang 
dipertanggungkan sampai pada waktu hutang dilunasi. Pelaksanaan asas itikad baik dalam perjanjian kredit juga memberikan hak bagi penerima gadai untuk menerima angsuran pokok pinjaman dan bunga sesuai dengan waktu yang ditentukan dan menjual barang gadai apabila pemberi gadai tidak memenuhi kewajibannya setelah batas waktu yang ditentukan untuk pemenuhan janjinya (H.S, 2001).

Mengenai dari kewajiban penerima gadai adalah menjaga barang yang digadaikan sebaikbaiknya, tidak di perkenankan untuk mengalihkan barang yang digadaikan menjadi miliknya walaupun pemberi gadai tidak memenuhi kewajibannya atau wanprestasi, dan bertanggung jawab atas kerugian barang gadai akibat kelalaiannya. Sahnya suatu perjanjian gadai tersebut didasarkan pada penyerahan benda yang digadaikan ke dalam penguasaan kreditur atau pihak ketiga yang ditunjuk bersama, apabila kebendaan yang digadaikan tersebut tetap berada di tangan debitur, maka hak gadainya tidak sah secara atau demi hukum (Prodjodikoro, 1981). Penyerahan itu harus nyata, tidak boleh hanya berdasarkan pernyataan dari debitur, sedangkan benda tersebut berada dalam kekuasaan debitur itu (Badrulzaman, 1995).

Berdasarkan hasil wawancara yang dilakukan dengan I Ketut Putrayasa yang berlokasi di Perumahan Wahyu Bemasi Permai, Banjar Bernasi Buduk, Desa Buduk, Kecamatan Mengwi, Kabupaten Badung, dalam rangka pelaksanaan asas itikad baik dalam perjanjian kredit atau mengamankan piutang kreditur, maka secara khusus oleh debitur kepada kreditur diserahkan suatu kebendaan bergerak yang dipergunakan sebagai jaminan pelunasan utang debitur yang menimbulkan hak bagi kreditur unruk melakukan penahanan atas benda bergerak yang digadaikan tersebut sampai dengan pelunasan utang debitur.

Perjanjian kredit secara lisan dengan jaminan gadai mobil yang dilakukan oleh Fery dan 1 Ketut Putrayasa telah memenuhi syarat sahnya perjanjian sesuai dengan Pasal 1320 KUHPerdata. Pelaksanaan asas itikad baik dalam perjanjian kredit secara lisan dengan jaminan gadai mobil yang dilakukan oleh Fery dan I Ketut Putrayasa ditafsirkan sebagai hal yang berhubungan dengan kepatuhan dan kepantasan dalam melaksanakan perjanjian tersebut sehingga harus dilaksanakan dengan itikad baik atau contractus bonafide. Perjanjian kredit secara lisan dengan jaminan gadai mobil telah dilakukan pelunasan oleh Fery kepada I Kerut Putrayasa sesuai dengan kesepakatan yang dibuat bersama. Fery kemudian kernbali ingin meminjam sejumlah uang kepada I Kerut Putrayasa dengan alasan ingin mudik dan anaknya sedang sakit. I Kerut Putrayasa kemudian merasa iba dengan hal-hal yang telah disampaikan oleh Fery, maka I Ketut Putrayasa kemudian memberikan pinjaman sejumlah uang yaitu sebesar Rp. 40.000.000,-(empat puluh juta Rupiah) dengan ketentuan dan syarat yang sama sebagaimana perjanjian lisan yang dibuat sebelumnya. Namun, setelah berjalan selama 5 (lima) bulan dan waktu jatuh tempo telah Jewat, tidak terdapat kabar dari Fery untuk melakukan pelunasan atas sejumlah uang yang telah diterimanya.

I Ketut Putrayasa kemudian menanyakan kepada kerabat Fery mengenai keberadaannya. Narnun, sahabatnya mengatakan bahwa Fery sudah tidak berada di kampung halamannya lagi. Selain iru, mobil yang menjadi jaminan gadai tersebut ternyata tidak terdaftar karena Buku Pemilik Kendaraan Bermotor (BPKB) ditahan oleh pihak dealer Toyota dan Surat Tanda Kendaraan Bermotor (STNK) yang diberikan tersebut palsu. Berdasarkan hal tersebut, dapat diketahui bahwa, Fery tidak memiliki itikad baik dalam melaksanakan perjanjian kredit secara lisan dengan jaminan gadai mobil yang dilakukannya dengan I Ketut Putrayasa.

I Ketut Putrayasa sebagai pihak yang dirugikan, dapat rnenuntut atas kerugian yang dideritanya kepada Fery. Pasal 1365 Kitab Undang-undang Hukum Perdata telah menyebutkan bahwa tiap perbuatan melanggar hukum yang membawa kerugian kepada orang lain, mewujudkan orang yang karena salahnya menerbitkan kerugian iru, mengganti kerugian tersebut. Fery tidak melaksanakan perjanjian kredit secara lisan dengan jaminan gadai mobil dengan itikad baik dan melakukan tipu daya atau tipu muslihat kepada I Ketut Putrayasa karena memberikan informasi maupun surat-surat kendaraan yang tidak benar atau palsu. 


\section{SIMPULAN DAN SARAN}

\section{Simpulan}

Sahnya perjanjian kredit secara lisan dengan jaminan gadai mobil diatur dalam Pasal 1320 KUHPerdata yaitu sepakat untuk mengikatkan dirinya, kecakapan untuk membuat suatu perjanjian, suaru hal tertentu dan suatu sebab yang halal. Perjanjian kredit secara lisan yang dilakukan oleh Fery dan I Ketut Putrayasa telah memenuhi semua syarat-syarat tersebut. Terdapat kesepakatan Fery meminjam uang sebesar Rp30.000.000,- (tjga puluh juta Rupiah) kepada I Ketut Putrayasa dengan memberikan jaminan sebuah mobil Toyota Vios, memiliki kecakapan karena telah berumur diatas 21 tahun, terdapat hal tertentu berupa objek perjanjian yang jelas, dan suatu sebab yang halal karena perjanjian lisan yang dibuat oleh Fery dan I Ketut Putrayasa tidak bertentangan dengan Peraturan Perundang-undangan yang berlaku.

Pelaksanaan asas itikad baik dalam perjanjian kredit secara lisan dengan jaminan gadai mobil yaitu terkait dengan kejujuran yang terletak pada sikap batin kedua belah pihak, yang telah disampaikan secara lisan berdasarkan kepercayaan atau keyakinan, kejujuran serta kemauan baik dari kedua belah pihak. Fery telah melaksanakan dengan itikad baik hal-hal yang disepakati dalam perjanjian yang dibuat bersama dengan I Ketut Putrayasa tanpa terdapat pelanggaran apapun dengan melakukan pelunasan terhadap pinjaman yang dilakukannya kepada Ketut sebesar Rp30.000.000,(tiga puluh juta Rupiah) dalam tempo waktu 5 (lima) bulan dengan bunga atas pinjaman tersebut sebesar 10\% (sepuluh persen) per bulan. Namun, terkait dengan pinjaman Fery berikutnya sebesar Rp40.000.000,- (empat puluh juta Rupiah), Fery tidak melaksanakan perjanjian kredit secara lisan dengan itikad baik karena tidak melakukan pelunasan terhadap pinjaman tersebut sesuai kesepaktan yang telah dibuat bersama serta melakukan tipu daya atau tipu muslihat kepada I Ketut Putrayasa karena memberikan informasi maupun surat-surat kendaraan yang tidak benar atau palsu.

\section{Saran}

Pemerintah perlu untuk membuat kebijakan dan memberikan sosialisasi agar masyarakat memahami bahwa perjanjian yang dibuat secara tidak tertulis atau lisan juga mengikat secara hukum bagi para pihak yang membuatnya serta sah apabila memenuhi unsur yang terdapat di dalam rumusan Pasal 1320 KUHPerdata. Sehingga pemerintah melalui aparat penegak hukum dapat menindak tegas pihakpihak yang tidak melaksanakan hal-hal yang telah disepakatinya, meskipun dilaksanakan secara lisan. Selain itu, para pihak yang melakukan perjanjian harus memperhatikan syarat sahnya perjanjian seperti kesepakatan, kecakapan, suatu hal tertentu, dan suatu sebab yang halal karena apabila hal tersebut tidak terpenuhi maka, perjanjian tersebut dapat dibatalkan atau dapat batal demi hukum.

Sepanjang perjanjian tersebut telah sesuai dengan syarat sahnya perjanjian, maka perjanjian tersebut memiliki kekuatan hukum yang mengikat para pihak. Selanjutnya, masyarakat perlu memahami mengenai perjanjian apabila dibuat secara lisan dan apabila menjadi pihak dalam perjanjian lisan, maka harus melaksanakan apa yang telah disepakati dengan itikad baik, tidak merugikan satu sama lainnya serta selalu mengindahkan norma-norrna kesusilaan, kepatutan, kebiasaan, dan undang-undang agar perjanjian tercipta dengan baik tanpa adanya pihak yang dirugikan.

\section{DAFTAR PUSTAKA}

Amalia, R., Sabrie, H. Y., \& Dian, W. (2018). The Principle of Good Faith in The Choice of Law of Foreign Direct Investment Contracts in Indonesia. Fiat Justisia: Jurnal Ilmu Hukum, 12(2), 170180.

Atmaja, I. D. G., \& Budiartha, I. N. P. (2018). Teori-Teori Hukum. Setara Press. Malang.

Badrulzaman, M. D. (1995). Perjanjian Baku (standar) Perkembangannya di Indonesia. Alumni. Bandung.

H.S, S. (2001). Pengantar Hukum Perdata Tertulis (BW). Sinar Grafika. Jakarta.

Fuady, M. (2003). Jaminan Fidusia (Cetakan II). PT. Citra Aditya Bakti. Bandung.

Miru, A. (2007). Hukum Kontrak dan Perancangan. PT Grafindo Persada. Jakarta.

Prodjodikoro, W. (1981). Hukum Perdata Tentang Persetujuan Tertentu. Alumni. Bandung.

Sirait, M. D., Kosasih, J. I., \& Arini, D. G. D. (2020). Asas Itikad Baik dalam Perjanjian Sewa-

Menyewa Rumah Kantor. Jurnal Analogi Hukum, 2(2), 221-227.

Tiong, O. H. (1985). Fidusia Sebagai Jaminan Unsur-Unsur Perikatan. Ghalian Indonesia. Jakarta. 
Untung, B. (2000). Kredit Perbankan di Indonesia. Andi. Yogyakarta.

Vijayantera, I. W. A. (2020). Kajian Hukum Perdata Terhadap Penggunaan Perjanjian Tidak Tertulis dalam Kegiatan Bisnis. Jurnal Komunikasi Hukum, 6(1), 115-125.

Wauran, R. V., R, S. A., \& Tampi, B. (2020). Kepastian Hukum Perjanjian Secara Lisan Menurut KUHPerdata Pasal 1338. Jurnal Lex Privatum, 8(2), 86-95.

Undang-Undang Dasar Negara Republik Indonesia Tahun 1945.

Kitab Undang-Undang Hukum Perdata.

Undang-Undang Nomor 21 Tahun 2011 tentang Otoritas Jasa Keuangan. 